\title{
Realising New Open Educational Resources Achievement during Open and Distance Learning of First Year Local Accounting Undergraduates
}

Noor Saatila Mohd Isa, Norliana Omar, Siti Marlia Shamsuddin \& Irda Syahira Khair Anwar

To Link this Article: http://dx.doi.org/10.6007/IJARBSS/v12-i1/11206

DOI:10.6007/IJARBSS/v12-i1/11206

Received: 14 November 2021, Revised: 17 December 2021, Accepted: 27 December 2021

Published Online: 05 January 2022

In-Text Citation: (Isa et al., 2022)

To Cite this Article: Isa, N. S. M., Omar, N., Shamsuddin, S. M., \& Anwar, I. S. K. (2022). Realising New Open Educational Resources Achievement during Open and Distance Learning of First Year Local Accounting Undergraduates. International Journal of Academic Research in Business and Social Sciences, 12(1), 187202.

Copyright: (c) 2022 The Author(s)

Published by Human Resource Management Academic Research Society (www.hrmars.com)

This article is published under the Creative Commons Attribution (CC BY 4.0) license. Anyone may reproduce, distribute, translate and create derivative works of this article (for both commercial and non0-commercial purposes), subject to full attribution to the original publication and authors. The full terms of this license may be seen

at: http://creativecommons.org/licences/by/4.0/legalcode

Vol. 12, No. 1, 2022, Pg. 187 - 202

Full Terms \& Conditions of access and use can be found at http://hrmars.com/index.php/pages/detail/publication-ethics 


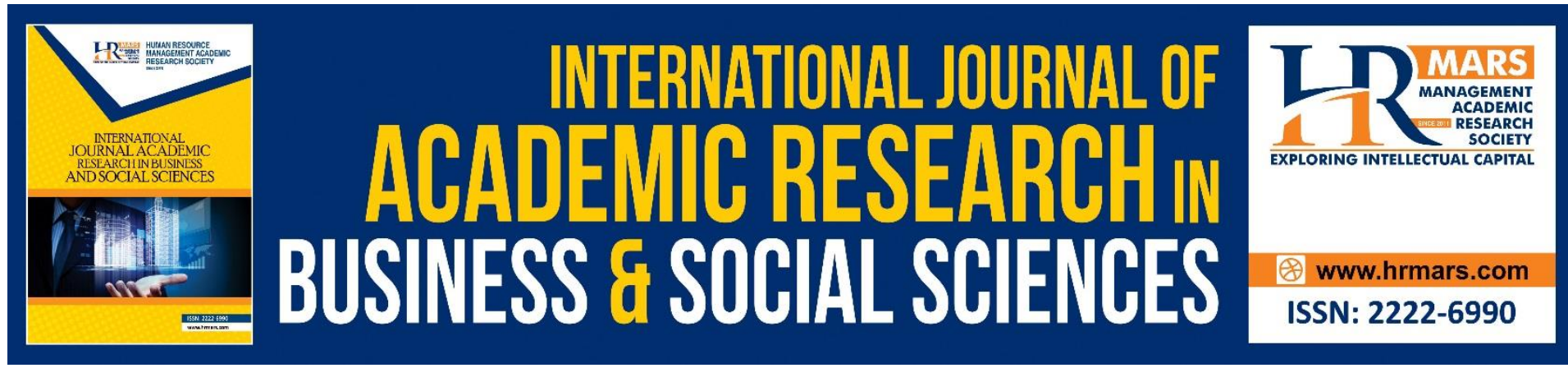

\title{
Realising New Open Educational Resources Achievement during Open and Distance Learning of First Year Local Accounting Undergraduates
}

\section{Noor Saatila Mohd Isa, Norliana Omar, Siti Marlia Shamsuddin \& Irda Syahira Khair Anwar}

Faculty of Accountancy, Universiti Teknologi MARA, Perak Branch, Tapah Campus, 35400,

Tapah Road, Perak, Malaysia

Email: noors464@uitm.edu.my,norli793@uitm.edu.my, sitim008@uitm.edu.my, irdas360@uitm.edu.my

\begin{abstract}
Since the pandemic crisis of COVID -19 arose around the world, the education system has changed significantly; from the traditional face-to-face (F2F) classes to Open and Distance Learning (ODL) mode. This is when Open Educational Resources (OER) gained its popularity. Consequently, the privilege of educational institutions in providing knowledge to students has changed and that knowledge is no longer under the exclusive control of educators. The role of teachers in the context of conducting the learning process in the classroom is getting replaced with ICT supported learning tools. This study investigated the experiences of the first year local Accounting undergraduates from a local public university in using OER during their ODL session. The data were collected by using an electronic survey asking about advantages, compatibility, trial-ability, visibility and also difficulties of using OER during ODL. The result shows that the majority of respondents opted from Agree to Strongly Agree to all the questions. These responses demonstrated the successful movement from traditional resources (printed textbooks and hardcopy notes) and early stage of OER implementation (MOOCS) to a further step ahead in the usage of OER during ODL classes (video-conferencing, live streaming and recorded audio and video being uploaded in YouTube).
\end{abstract}

Keywords: Open Educational Resources, Open and Distance Learning, Accounting Undergraduates, OER Experiences, OER Implementation.

Introduction

According to Statistics of Higher Education 2020, Malaysia currently serves 1,224,098 enrolments of students in higher learning institutions under the supervision of the Ministry of Higher Education (MOHE). At the higher education level, textbooks are recommended by individual lecturers or universities to be purchased by students for their studies. Textbooks are generally recognised as vital learning resources at colleges and universities (Hilton, 2016). Based on the report by USIM et al. (2017), Malaysian students spent over MYR234 million per year on textbooks. Since textbooks represent a significant percentage of expenses faced by 
university students, efforts should be focused to reduce the rising cost of higher education. This is particularly right to consider the potential of Open Educational Resources (OER) as a worthwhile option to make education more accessible and affordable.

OER is defined as teaching and learning resources such as textbooks, multimedia, tests, software and assessments that reside in the public domain or have been released under an intellectual property license that permit the free use and repurposing of the resources by others (Abramovich and McBride, 2018; Hilton, 2016). Before the COVID-19 pandemic hit worldwide, the movement to OER has gotten a modest start in higher learning institutions in Malaysia due to a lack of broad understanding of OER. Only several higher educational institutions have implemented OER earlier in line with the Malaysian Education Blueprint 2015-2025 (Higher Education) transformation. The document highlighted 10 shifts that will spur continuous excellence in the higher education system, one of them is to globalise online learning.

Previously, OER were only demanded by adult learners that enrolled for distance learning course and as a mechanism to promote Malaysia as an international education hub for overseas students. However, the COVID-19 outbreak has changed the education system globally. Now, everyone is learning in the Open and Distance Learning (ODL) mode, either educators or students, they have to change along with it. Due to these ODL courses, awareness about OER is gradually growing. The role of academic staff now is being expanded from the traditional elements of research and teaching to a broader role encompassing all elements relating to the discovery, integration, interpretation and application of knowledge as stated in Malaysia Education Blueprint 2015-2025.

In order to move Malaysia to one where technology-enabled innovations are harnessed to make education more accessible, this study was intentionally done to investigate the experiences of the first-year accounting undergraduates in a local public university in using OER during their ODL session. The adoption and expansion of OER with the aid of information and communication technology (ICT) such as Massive Open Online Courses (MOOCs) have started a few years back in this institution. In addition to that, this effort has become more prominent during ODL sessions as its educators are changing drastically from traditional lectures in face-to-face classes to video-conferencing, live streaming and recorded audio and video being uploaded in YouTube. However, in this study OER efforts are focusing on lecture and learning materials purposes only.

Therefore, the objectives of this study are:

i) To understand the level of experience of Accounting undergraduates in using OER during ODL

ii) To seek the difference of Grade Point Average (GPA) scores between the early stage of OER implementation during face-to-face (F2F) and the progressing stage of OER implementation during ODL of the first semester Accounting undergraduates

iii) To seek the difference between gender and GPA scores of the first-semester Accounting undergraduates during the stages of OER implementation. 


\section{Literature Review \\ Open Educational Resources (OER) and Student's Performance}

During the last few years, the adoption of Open Educational Resources (OER) has become a major trend in higher education since it has been successful in reducing the cost of educational materials. In line with the rise in implementing OER practices especially during the pandemic crisis, there have been numerous findings discovered on the effectiveness and implications of these educational policies towards academic performance. Overall, previous researchers have produced somewhat mixed results.

Students are mostly motivated to accept the application of OER by the opportunity to earn extra credit and desire to achieve a favourable grade (Ward and Lindshield, 2020). According to Farrow et al (2015), OER may indirectly improve student performance through increased satisfaction, engagement and interest in the subjects. Past works of the literature suggested that courses that have implemented OER, result in higher student grades (Feldstein et al., 2012), higher pass rates (Fischer et al., 2015) or lower failure and withdrawal rates (Feldstein et al., 2012) than courses that do not use OER materials. Adoption of OER would be effective as a learning intervention because it ensures that all students have access to the course materials and would therefore result in better learning outcomes. Venegas Muggli and Westermann (2019) demonstrated that first-year higher education students in face-to-face mathematical course classes who used OER resources obtained better examination grades than students who used the open textbook or relied on traditional proprietary textbooks. OER is assumed to be relevant because they facilitate learning processes by delivering diverse open-access materials and are easily accessible to students in a variety of disciplinary areas, including accounting. Little and Jones (2020) additionally verified that students completely performed better in online learning by using OER than in the traditional class. But when gender is taken into consideration, males performed much better in the exam grades for online learning with OER than traditional classes. Males did outperform females most probably because they feel that the new format of learning materials are more practical, user friendly and well capture their interest to learn.

Similarly, Kermanshachi and Nipa (2018) also revealed that the students using OER materials received higher grades than the students from the previous semester who had the same instructor but utilized traditional textbook-based materials. The academic performance of the students utilizing OER materials was better than that of the students using traditional textbooks specifically in terms of their assignments, exams and course projects. If the majority of the students have financial constraints, it is recommended for the academic course to consider the utilization of OER materials, as it reduces the burden of purchasing course textbooks. On the other hand, some studies found a negative effect regarding the implications of OER. OER practices may give rise to a negative effect if the students perceive a lack of support, low confidence level and consequently discourage them to adopt different versions of learning resources. Due to the sudden transition to OER, it might potentially deteriorate student's performance since they already get used to the previous traditional method. Indirectly, these students would then be at a learning disadvantage. This argument was further proved by prior findings who reported a negative effect of OER application in certain courses and semesters as compared to a commercial textbook (Fischer et al., 2015; WinitzkyStephens and Pickavance, 2017), subsequently lead to unfavourable learning outcomes.

However, other researchers do not find any significant difference in academic achievement between OER adoption and traditional learning material (Tang et al., 2020; Fialkowski et al., 2020). The final course grades of students in the OER class were on a par with the 
performance in traditional textbook classes (Chang, 2020). Consistently, Hilton (2016) found that students enrolled in courses that have implemented OER as the textbook perform just as well in comparison to students enrolled in courses that use traditional commercial textbooks. An OER may be an appropriate solution for institutions seeking to decrease the financial problems students face. There are no significant differences between the performances of students using traditional standard textbooks with the newly introduced OER resources but it is believed that OER resources could be a valuable asset in higher education. The fact that students were able to save a considerable amount of money without compromising their performance or quality learning is a substantial benefit for considering the OER resources (Mathew and Kashyap, 2019). Results from a study done by Zhao et al (2020) also indicated that courses using OER compared to non-OER courses did not produce a statistically significant change in grades (failing and D-grades). Student performance generally did not decrease but there is a decreased rate in student course withdrawal and a better retention rate for courses using OER.

\section{Benefits and Drawbacks of OER}

Over time, an extensive literature has been developed on the benefits and drawbacks of OER. According to Roeder et al (2017), in general, many institutions have been using textbooks as primary learning resources for all students as the quality is comparatively high. Therefore, the usage of the textbook in learning has been proven effective and valuable for students. In addition, as the demand for textbooks increases, it would result in the rising price of the textbooks, which has caused many students cannot afford them, especially students coming from lower-income families where their parents must meet these increasing costs. Although today the technology has become advanced, the students can access materials for their studies through digital publishing, but the rising price of the textbook continues. OER is the solution for the rising price of the textbook and is suitable for young students who are good at using technological devices as they will carry the devices such as smartphones or tablets in their pocket (Kermanshachi and Nipa, 2018). Swigart and Liang (2016) mentioned that the content of OER can be accessed at anytime and anywhere as long as the students have an internet connection. Therefore, the use of OER to replace the traditional textbook can substantially reduce the students' financial burden.

Krelja (2016); Howard (2019) supported that OER has become a great opportunity for everyone who wants to learn as the digital resources are accessible to everyone and can be adopted or adapted to the students' needs. The students only incur the cost of printing if they want to print out the materials. Roeder et al. (2017) emphasized that in Germany, the federal state educational framework allowed the teacher to freely choose their teaching materials as long as the topics specified to be taught are covered. Thus, OER provides an opportunity for teachers to use a variety of examples and materials from different sources and platforms compared to printed textbooks to increase the students' interest. Moreover, the teacher can also improve their teaching practice through collaboration in virtual communities learning and incorporation of user feedback. Krelja (2016) also reported that OER could reduce the gap between the strata of society and countries, and thus the quality of education can be improved.

Despite there are many advantages of OER, the past literature also found problems in using OER. Some students face issues in accessing OER because some resources require special software or applications to access the information needed (Krelja, 2016). In addition, some students fail to access the online materials due to limited accessibility or slow internet 
connection, mostly low-income families or those in rural areas (Debbarma and Durai, 2021). Some of the students lack computer literacy skills and thus faced difficulty finding relevant information when accessing OER (Sultan and Rafiq, 2021). Abramovich and McBride (2018) found that some students prefer printed materials rather than digital materials. OER allows everyone to create new content freely by editing and combining materials from various resources that contradict traditional learning, which permission is needed to adapt the resources (Abramovich and McBride, 2018). Therefore, considering most of the materials from OER come from various sources or platforms, anyone could have uploaded and edited the content of the materials, which has resulted in inaccurate and unreliable information being included. The incomplete or inaccurate information from OER has become a challenge for students (Sultan and Rafiq, 2021). Due to that, before the materials can be effectively used, the students need to review and identify whether the information is relevant, accurate and reliable to be used or not. The students must regularly take note of the updated materials or the newest information (Swigart and Liang, 2016).

Moreover, Roeder et al (2017) also found that some teachers lack adequate teaching materials and are challenging to develop necessary competencies for teaching. Thirdly, OER has caused the lack of human interaction between students and teachers as it disconnects face-to-face interaction (Mishra et al., 2020). Muthuprasad et al (2021) supported that the efficiency between conventional teaching in the classroom and online differs. For online teaching, the teachers use online applications such as Zoom, Google Meet, Microsoft Teams, Google Classroom as a medium for communication and sharing information with the students. Lastly, Abramovich and McBride (2018) argued that despite the optimistic view of OER, some students prefer the traditional course materials and prefer to pay rather than to accept a free version as the students are using the price to measure the quality.

\section{Impact of Pandemic Crisis over the Continuation of OER}

The pandemic of COVID-19 has caused a severe impact on our daily lives, economic and social disruption, including the education system. To reduce the spread of COVID-19, the lockdown has been implemented to restrict people from leaving their homes. Social lockdown is necessary to stop the rapid spread of the virus. Due to that, the entire education system in the world has collapsed with the closure of educational institutions such as schools, colleges, universities, as isolation is needed to control the situation (Muthuprasad et al., 2021). The other study mentioned that the closure of educational institutions and the continuous lockdown has caused mental stress such as frustration and depression among the students and affected their learning process (Debbarma and Durai, 2021; and Chaturvedi et al., 2021). Given the abruptness of the situation, the only option left as an emergency learning system is by adopting online teaching. In some countries, the schools and universities are reopened after the relaxation of restricted movement policy but with strict standard operating procedures, which is very challenging and significantly disturbed traditional educational practices.

During the pandemic of COVID-19, OER has been accepted widely from elementary to tertiary level to replace the traditional method with the modern approach and gradually replace the traditional classroom. Most of the countries implemented OER to facilitate student learning during the pandemic. Mishra et al. (2020) mentioned that the pandemic of COVID-19 had become a massive challenge with the sudden transition in the educational system, and not all are competent enough to embrace the current situation, especially those with technological 
complexity. Debbarma and Durai (2021) further supported that the educators and learners faced difficulties with adopting new learning methods. The traditional classrooms promote various active interactions and discussions between teachers and students, leading to an effective communication environment. In contrast, with OER, there is a lack of personal interaction or communication between teachers and students. The pandemic of COVID-19 has changed the delivery method of education significantly. Therefore, the students and teachers must continue to learn to use the variety of OER to enhance the teaching and learning system.

\section{Research Methodology}

This study was attended by first-year undergraduate accounting students from a local public university in Perak who had their first experience of ODL in semester 20202 when it was implemented. A set questionnaire was adapted from a previous study by Afolabi (2017) and was rephrase to suit the ODL sessions. It is used as a method of data collection that was sent through an e-survey using Google Form. The variables were demographic information, advantages of OER during ODL session (Variable 1), compatibility of OER during ODL with past experience (Variable 2), tri-ability of OER during ODL (Variable 3), visibility of OER result during ODL (Variable 4), and finally the difficulty and understand-ability of OER to be used during ODL (Variable 5). Scales from Strongly Disagree (1), Disagree (2), Agree (3) and Strongly Agree (4) are used to measure their experiences. A total of 108 samples of responses were collected from the e-survey out of a total population of 702 first-year undergraduates who were in the first and second semester of the Accounting program and were taking the same modules as prescribed by the institution in the respective study plan. Statistical analysis was performed using SPSS (Statistical Package for Social Science) software. Descriptive statistics were performed with the calculation of frequency and percentage for quantitative variables. Analysis of variance was also performed for further investigation.

Findings and Discussion

\begin{tabular}{|l|r|c|c|c|}
\hline & & Frequency & Percent (\%) & Cumulative Percent \\
\hline Gender & Female & 94 & 87 & 87 \\
& Male & 14 & 13 & 100 \\
\hline Part & 1 & 12 & 11.1 & 11.1 \\
& 2 & 96 & 88.9 & 100 \\
\hline Courses enrolled & 5 & 16 & 14.8 & 14.8 \\
& 6 & 75 & 69.4 & 84.3 \\
& 7 & 11 & 10.2 & 94.4 \\
& 8 & 6 & 5.6 & 100 \\
\hline
\end{tabular}

Table 1: Demographic Information

Table 1 shows the demographic information of respondents which $87 \%$ of total respondents are female. The majority of $88.9 \%$ of them were part 2 students, while part 1 was just $11.1 \%$. The data also shows that $69.4 \%$ which was the majority of respondents were taking 6 courses during the first semester of the ODL session, followed by $14.8 \%$ of 5 courses while the minimum number of students (5.6\%) was taking 8 courses during the current semester.

From Table 2 below, the mean score for the majority of items of the five variables are above the midpoint of 2 and two items which are i) The OER is a positive innovation (Variable) 1; and 
ii) Using OER would require me to change my study habit (Variable 2) scored above 3 points, in which highlighted that respondents agree with all the OER experiences. More than half of the total respondents chose to Agree to Strongly Agree with all their experiences when being asked about OER.

Item 1 for Variable 1 which is about the advantages of OER during ODL shows a total of $89.9 \%$ who opted for Agree to Strongly Agree. They said that OER during ODL is a positive innovation that will spur the lights of the realising improvement of OER in future semesters ahead if teaching and learning are still going to be conducted in ODL mode. This suggested that students can act innovatively in designing the framework of learning at their own creativity as they can watch interactive videos prepared by their lecturers in their own time and innovatively making their own notes by combining, reorganising them into the most practicable notes that suit their preferences rather than relying on proprietary textbooks only. These findings also show a good sign for teachers to creatively and innovatively plan for their teaching materials and videos as has been suggested by Roeder et al. (2017). While the highest score of Disagree-Strongly Disagree in this Variable 1 was shown by Item 2, where a total of $30.6 \%$ found that it is harder to communicate with teaching lecturers and friends who agree with OER during ODL sessions. Though the number is insignificant, in order for academic institutions to hit the improvements in the full implementation of OER, teachers have to try to reduce this communication gap with students. Alawamleh et al. (2020) stated in their previous study that the communication gaps during online learning will impede the productivity of students and increase the feeling of isolation. Moreover, students will feel lacking in human teachers students interaction (Mishra et al. 2020) which definitely not a good achievement especially when the main objective of OER being implemented during ODL is to increase students' participation and performance. 
INTERNATIONAL JOURNAL OF ACADEMIC RESEARCH IN BUSINESS AND SOCIAL SCIENCES Vol. 12, No. 1, 2022, E-ISSN: 2222-6990 ๑ 2022 HRMARS

\begin{tabular}{|c|c|c|c|c|c|c|}
\hline \multirow[t]{2}{*}{ Variables } & \multicolumn{4}{|c|}{$\begin{array}{c}\text { Frequency \& Percentage of } \\
\text { Scales }\end{array}$} & \multicolumn{2}{|c|}{ Measurement } \\
\hline & SD & D & A & SA & Mean & $\boldsymbol{\sigma}$ \\
\hline \multicolumn{7}{|c|}{$\begin{array}{l}\text { Variable 1. Does Open Educational Resources (OER) during ODL have user advantage? ( } \alpha= \\
0.878 \text { ) }\end{array}$} \\
\hline $\begin{array}{l}\text { i. The OER during the ODL is a positive } \\
\text { innovation }\end{array}$ & $\begin{array}{c}1 \\
(0.9 \%)\end{array}$ & $\begin{array}{c}10 \\
(9.3 \%)\end{array}$ & $\begin{array}{c}83 \\
(76.9 \%)\end{array}$ & $\begin{array}{c}14 \\
(13.0 \%)\end{array}$ & 3.02 & 0.511 \\
\hline $\begin{array}{l}\text { ii. OER during the ODL makes it more } \\
\text { convenient to communicate with } \\
\text { teaching lecturers and friends }\end{array}$ & $\begin{array}{c}7 \\
(6.5 \%)\end{array}$ & $\begin{array}{c}26 \\
(24.1 \%)\end{array}$ & $\begin{array}{c}65 \\
(60.2 \%)\end{array}$ & $\begin{array}{c}10 \\
(9.3 \%)\end{array}$ & 2.72 & 0.721 \\
\hline iii. Using OER during the ODL saves time & $\begin{array}{c}6 \\
(5.6 \%) \\
\end{array}$ & $\begin{array}{c}17 \\
(15.7 \%)\end{array}$ & $\begin{array}{c}69 \\
(63.9 \%)\end{array}$ & $\begin{array}{c}16 \\
(14.8 \%)\end{array}$ & 2.88 & 0.720 \\
\hline $\begin{array}{l}\text { iv. OER during the ODL is the fast and } \\
\text { efficient way of getting information }\end{array}$ & $\begin{array}{c}4 \\
(3.7 \%) \\
\end{array}$ & $\begin{array}{c}17 \\
(15.7 \%)\end{array}$ & $\begin{array}{c}65 \\
(60.2 \%)\end{array}$ & $\begin{array}{c}22 \\
(20.4 \%)\end{array}$ & 2.97 & 0.716 \\
\hline \multicolumn{7}{|c|}{ Variable 2. Is using OER during the ODL compatible with your past experience? $(\alpha=0.731)$} \\
\hline $\begin{array}{l}\text { i. Using OER during the ODL would require } \\
\text { me to change my study habit } \\
\end{array}$ & $\begin{array}{c}1 \\
(0.9 \%) \\
\end{array}$ & $\begin{array}{c}17 \\
(15.7 \%) \\
\end{array}$ & $\begin{array}{c}67 \\
(62.0 \%) \\
\end{array}$ & $\begin{array}{c}23 \\
(21.3 \%) \\
\end{array}$ & 3.04 & 0.640 \\
\hline $\begin{array}{l}\text { ii. I am eager to respond to the discussion } \\
\text { group on OER during the ODL via } \\
\text { Learning Management System (For e.g: } \\
\text { through Google Classroom, uFuture, etc) }\end{array}$ & $\begin{array}{c}2 \\
(1.9 \%)\end{array}$ & $\begin{array}{c}34 \\
(31.5 \%)\end{array}$ & $\begin{array}{c}60 \\
(55.6 \%)\end{array}$ & $\begin{array}{c}12 \\
(11.1 \%)\end{array}$ & 2.76 & 0.668 \\
\hline $\begin{array}{l}\text { iii. OER during the ODL is compatible with } \\
\text { the way I work }\end{array}$ & $\begin{array}{c}4 \\
(3.7 \%) \\
\end{array}$ & $\begin{array}{c}29 \\
(26.9 \%) \\
\end{array}$ & $\begin{array}{c}64 \\
(59.3 \%) \\
\end{array}$ & $\begin{array}{c}11 \\
(10.2 \%) \\
\end{array}$ & 2.76 & 0.682 \\
\hline $\begin{array}{l}\text { iv. Using OER during the ODL increases my } \\
\text { interaction with the subject matter }\end{array}$ & $\begin{array}{c}7 \\
(6.5 \%) \\
\end{array}$ & $\begin{array}{c}29 \\
(26.9 \%)\end{array}$ & $\begin{array}{c}61 \\
(56.5 \%)\end{array}$ & $\begin{array}{c}11 \\
(10.2 \%) \\
\end{array}$ & 2.70 & 0.740 \\
\hline \multicolumn{7}{|c|}{ Variable 3. Does OER during the ODL allow trial-ability? $(\alpha=0.712)$} \\
\hline i. OER during the ODL does not terrify me & $\begin{array}{c}6 \\
(5.6 \%) \\
\end{array}$ & $\begin{array}{c}33 \\
(30.6 \%) \\
\end{array}$ & $\begin{array}{c}62 \\
(57.4 \%) \\
\end{array}$ & $\begin{array}{c}7 \\
(6.5 \%) \\
\end{array}$ & 2.65 & 0.688 \\
\hline $\begin{array}{l}\text { ii. I do trial and error in wo } \\
\text { during the ODL }\end{array}$ & $\begin{array}{c}2 \\
(1.9 \%) \\
\end{array}$ & $\begin{array}{c}38 \\
(35.2 \%)\end{array}$ & $\begin{array}{c}62 \\
(57.4 \%)\end{array}$ & $\begin{array}{c}7 \\
(6.5 \%) \\
\end{array}$ & 2.67 & 0.611 \\
\hline $\begin{array}{l}\text { iii. I am confident in my ability to use OER } \\
\text { during the ODL }\end{array}$ & $\begin{array}{c}2 \\
(1.9 \%) \\
\end{array}$ & $\begin{array}{c}9 \\
(8.3 \%) \\
\end{array}$ & $\begin{array}{c}82 \\
(75.9 \%)\end{array}$ & $\begin{array}{c}15 \\
(13.9 \%) \\
\end{array}$ & 3.02 & 0.547 \\
\hline $\begin{array}{l}\text { iv. I can learn at a comfortable pace using } \\
\text { OER during the ODL }\end{array}$ & $\begin{array}{c}4 \\
(3.7 \%) \\
\end{array}$ & $\begin{array}{c}27 \\
(25.0 \%) \\
\end{array}$ & $\begin{array}{c}63 \\
(58.3 \%) \\
\end{array}$ & $\begin{array}{c}14 \\
(13.0 \%) \\
\end{array}$ & 2.81 & 0.703 \\
\hline \multicolumn{7}{|c|}{ Variable 4. Is the result of using OER visible to you? $(\alpha=0.701)$} \\
\hline $\begin{array}{l}\text { i. I am aware of OER before I got } \\
\text { admission }\end{array}$ & $\begin{array}{c}1 \\
(0.9 \%) \\
\end{array}$ & $\begin{array}{c}26 \\
(24.1 \%) \\
\end{array}$ & $\begin{array}{c}71 \\
(65.7 \%) \\
\end{array}$ & $\begin{array}{c}9 \\
(8.3 \%) \\
\end{array}$ & 2.82 & 0.580 \\
\hline ii. OER makes teaching real during the ODL & $\begin{array}{c}5 \\
(4.6 \%) \\
\end{array}$ & $\begin{array}{c}33 \\
(30.6 \%) \\
\end{array}$ & $\begin{array}{c}61 \\
(56.5 \%) \\
\end{array}$ & $\begin{array}{c}8 \\
(7.4 \%) \\
\end{array}$ & 2.67 & 0.684 \\
\hline iii. I have seen other university using OER & $\begin{array}{c}2 \\
(1.9 \%) \\
\end{array}$ & $\begin{array}{c}19 \\
(17.6 \%)\end{array}$ & $\begin{array}{c}72 \\
(66.7 \%)\end{array}$ & $\begin{array}{c}15 \\
(13.9 \%)\end{array}$ & 2.93 & 0.622 \\
\hline \multicolumn{7}{|c|}{ Variable 5. Is OER during the ODL difficult to be use and understand? ( $\alpha=0.835$ ) } \\
\hline i. OER during the ODL is user friendly & $\begin{array}{c}3 \\
(2.8 \%) \\
\end{array}$ & $\begin{array}{c}16 \\
(14.8 \%)\end{array}$ & $\begin{array}{c}78 \\
(72.2 \%)\end{array}$ & $\begin{array}{c}11 \\
(10.2 \%)\end{array}$ & 2.90 & 0.595 \\
\hline
\end{tabular}




\begin{tabular}{|l|c|c|c|c|c|c|}
\hline ii. When using OER during the ODL, I find it \\
$\begin{array}{l}\text { easy to navigate from one screen to } \\
\text { another }\end{array}$ & $\begin{array}{c}6 \\
(5.6 \%)\end{array}$ & $\begin{array}{c}18 \\
(16.7 \%)\end{array}$ & $\begin{array}{c}75 \\
(69.4 \%)\end{array}$ & $\begin{array}{c}9 \\
(8.3 \%)\end{array}$ & 2.81 & 0.662 \\
\hline $\begin{array}{l}\text { iii. I am confident in my ability to use OER } \\
\text { during the ODL }\end{array}$ & $\begin{array}{c}2 \\
(1.9 \%)\end{array}$ & $\begin{array}{c}32 \\
(29.6 \%)\end{array}$ & $\begin{array}{c}63 \\
(58.3 \%)\end{array}$ & $\begin{array}{c}9 \\
(8.3 \%)\end{array}$ & 2.75 & 0.633 \\
\hline
\end{tabular}

$A=$ Agree; $S A=S t r o n g l y$ Agree; $D=$ Disagree; $S D=S t r o n g l y$ Disagree

Table 2: Descriptive Analysis of Variables

Item 1 in Variable 2, shows the highest score for Agree-Strongly Agree with a total of 83.3\%, when using OER during ODL, respondents have to change their study habits. The reason is due to the fact that learning content through OER in this institution is performed dynamically instead of static when students are encouraged to ask questions, make adjustments of prior learning to incorporate new ideas, testing of understanding and giving feedback which has led to increment towards a positive side of their study habit and interaction in the subject matter. Furthermore, these findings also suggested that changes in their study habit in using OER during ODL are also high due to the reason that OER support compatibility of students way of life during this pandemic crisis of COVID-19. OER during ODL has become a great opportunity for students who want to learn while having to perform the part-time job to support their life, as the learning materials are accessible to everyone that can be adopted or adapted to the students' needs and way of life (Krelja, 2016; Howard, 2019). Item 2 and 4 show the highest score for Disagree-Strongly Disagree with $33.4 \%$ are not eager to respond to group discussion using OER during ODL on OER during the ODL via Learning Management System (LMS) and using OER during ODL will not increase their interaction in the subject matter. However, this number is insignificant but more attention needs to be put to those related features that will turn OER from raw content into a useful learning experience. This means teachers need to build learning experiences or atmospheres into which the OER will fit and eventually students will benefit from it. Teachers have to improvise the way group discussion is conducted that will attract these students' participation and thus increase their interaction. Teachers may choose amongst the proposed LMS, such as Google Classroom, uFuture and any others to support this group discussion, because Rahman et al (2019) suggested that LMS may facilitate students in their learning process.

Next, a total of $89.9 \%$ of the respondents Agree-Strongly Agree by Item 3 in the 3rd variable as they are confident with their ability in using OER during ODL. As first-year undergraduates, it is good to note that majority of them were not intimidated but developed more confidence in their ability to use OER. This high confidence level could be due to one of the reasons that these students may have got great exposure to technology in previous years while they were in secondary schools. Being technology savvy is an advantageous trait that could help them fostering well in adaptation to OER during ODL. This is supported by a previous study (Kermanshachi and Nipa, 2018) where students who are good at using technological devices will excel in OER. The highest total of $36.1 \%$ of Disagree-Strongly Disagree is shown by Item 1 of Variable 3, as they do think that OER in ODL is somehow terrifying for them. This minority group could have come from the group of students who were not getting enough exposure to technology in previous secondary schools or lack of computer literacy skills and thus faced difficulty when accessing OER (Sultan and Rafiq, 2021). Another factor that has caused this worrisome issue among them could be due to the sudden transition of adaptation of OER 
during ODL sessions because they have already comfortable enough doing traditional faceto-face classroom mode as what they have experienced in secondary schools.

Item 3 for Variable 4, shows the highest score for Agree-Strongly Agree (a total of $80.6 \%$ ) of when respondents who have seen other universities that have already using OER. They are also already aware (74\%) of OER before they got admitted to this institution. This is also another added advantage to this institution because the majority of students have had the knowledge even not so much but rather have heard about OER before they entered this institution. The study believes that, if observability is completely established then the rate of acceptance is grander. Thus, the knowledge of students about OER is parallel with realising OER achievement in ODL for better progress in this institution. Despite the background and difficulty, they experienced during the period of transition from secondary school to university's life, the majority of students Agree-Strongly Agree (63.9\%) that OER during ODL made teaching more real compared to traditional face-to-face learning using textbooks, manuals and printed handouts. This finding is contradicted with the previous studies by Fischer et al. (2015); Winitzky-Stephens and Pickavance, (2017) who reported that using OER as compared to the traditional textbook will lead to unfavourable learning outcomes because OER has caused the lack of human interaction between students and teachers as it disconnects face-to-face interaction (Mishra et al. 2020).

A total of $82.4 \%$ of respondents opted for Agree-Strongly Agree with Item 1 of Variable 5 as they see OER during ODL is user friendly. This suggested that these Gen-Z students who had the knowledge about technology and electronic devices would favour adopting OER during ODL as they will benefit from it the most. Apart from that, these findings suggested OER during ODL in this institution is friendly because it can be easily accessed at anytime and anywhere (Krelja, 2016; Howard, 2019) as long as the internet connection is good. Then, having OER during ODL is also friendly because it can replace traditional textbooks which will reduce students' financial burden (Swigart and Liang, 2016), but rather students just have to incur a small amount of cost if they want to print the notes.

\begin{tabular}{|l|c|c|c|c|c|}
\hline & Sum of squares & Df & Mean Square & $F$ & Sig. \\
\hline Between Groups & 7.497 & 2 & 3.748 & 25.810 & .000 \\
\hline Within Groups & 90.624 & 624 & .145 & & \\
\hline Total & 98.121 & 626 & & & \\
\hline
\end{tabular}

Table 3: GPA - Analysis of variance

This study is concerned with the Grade Point Average (GPA) scores of 3 batches of students during the time OER was at an early stage of implementation that was in the traditional classroom session and during a progressing stage in the ODL mode. The main reason for this 3 batches comparison being made, is because present (semester 20202) part 1 students are from the second intake of admission to the university, same as Part 1 students in semester 20192, while part 1 students from semester 20194 were from the first intake of admission. Table 3, shows that the GPAs score for these 3 groups is significant at 0.000 which made this study had a further analysis of multiple comparisons to find which group has the significant effect of GPAs during OER stages. 
INTERNATIONAL JOURNAL OF ACADEMIC RESEARCH IN BUSINESS AND SOCIAL SCIENCES Vol. 12, No. 1, 2022, E-ISSN: 2222-6990 @ 2022 HRMARS

\begin{tabular}{|c|c|c|c|c|c|c|}
\hline \multirow{2}{*}{$\begin{array}{c}\text { GPA for } \\
\text { Part } 1 \\
\text { in semester } \\
\text { (I) }\end{array}$} & \multirow{2}{*}{$\begin{array}{l}\text { GPA for Part } 1 \\
\text { in semester } \\
\text { (J) }\end{array}$} & \multirow{2}{*}{$\begin{array}{c}\text { Mean } \\
\text { Difference } \\
(I-J)\end{array}$} & \multirow{2}{*}{$\begin{array}{l}\text { Std. } \\
\text { Error }\end{array}$} & \multirow[t]{2}{*}{ Sig. } & \multicolumn{2}{|c|}{ 95\% Confidence Interval } \\
\hline & & & & & $\begin{array}{l}\text { Lower } \\
\text { Bound }\end{array}$ & $\begin{array}{l}\text { Upper } \\
\text { Bound }\end{array}$ \\
\hline \multirow[t]{2}{*}{$\begin{array}{r}\text { Sem } \\
20202^{\wedge}\end{array}$} & $\begin{array}{r}\text { Sem } 20194 \\
>\end{array}$ & -.02025 & .06112 & .741 & -.1403 & .0998 \\
\hline & $\begin{array}{r}\text { Sem } \\
20192>\end{array}$ & $.34718^{*}$ & .07616 & .000 & .1976 & .4967 \\
\hline \multirow[t]{2}{*}{$\begin{array}{r}\text { Sem } \\
20194> \\
\end{array}$} & $\begin{array}{r}\text { Sem } 20202 \\
\wedge\end{array}$ & .02025 & .06112 & .741 & -.0998 & .1403 \\
\hline & $\begin{array}{r}\text { Sem } 20192 \\
>\end{array}$ & $.36743^{*}$ & .05119 & .000 & .2669 & .4679 \\
\hline \multirow[t]{2}{*}{$\begin{array}{r}\text { Sem } \\
20192>\end{array}$} & $\begin{array}{r}\text { Sem } 20202 \\
\wedge\end{array}$ & $-.34718^{*}$ & .07616 & .000 & -.4967 & -.1976 \\
\hline & $\begin{array}{r}\text { Sem } 20194 \\
>\end{array}$ & $-.36743^{*}$ & .05119 & .000 & -.4679 & -.2669 \\
\hline
\end{tabular}

$\wedge$ = A progressing stage of OER implementation during ODL mode (video-conferencing, live streaming and recorded audio and video being uploaded in YouTube. Focusing on lecture and learning materials purposes only)

$>=$ Early stage of OER implementation during traditional classroom mode (supported with Massive Open Online Courses (MOOCs))

Table 4: Multiple Comparison Analysis

Table 4 shows the multiple comparison analysis for Part 1 GPAs score for 3 different batches of students in their relevant semesters respectively. GPAs score for Part 1 students during semester 20202 is significant at 0.000 with GPAs score for Part 1 students in semester 20192. The same goes for GPAs score for Part 1 students in semester 20194 with GPAs score for Part 1 students in semester 20192 is also significant at 0.000 . Thus, it shows that GPA scores do have significant differences in the early stage of OER implementation (traditional classroom mode) comparing to progressing stage of OER implementation during ODL mode. The higher performance of part 1 students in semester 20202, is because the progressing stage of OER implementation has started during the current semester. This is aligned with past works of literature (Feldstein et al., 2012; and Fischer et al., 2015) where courses that have implemented OER results in higher student grades. However, the GPAs score for Part 1 students in semester 20202 was not significant with the GPAs score for part 1 students in semester 20194. This suggested that GPA scores for first intake students have no significant difference with second intake students during the stages of OER implementation. It might be due to the reason that the students for both intakes perceived the use of the OER method makes their learning easier and useful which in turn facilitated them to achieve better GPA grades. Furthermore, it is because first intake students were from prime stream who were admitted into the university based on their high performance in secondary educations' results. 


\begin{tabular}{|c|c|c|c|c|c|c|c|c|c|c|}
\hline & \multicolumn{2}{|c|}{$\begin{array}{l}\text { Levene's } \\
\text { Test for } \\
\text { Equality of } \\
\text { Variances }\end{array}$} & \multicolumn{7}{|c|}{ t-test for Equality of Means } \\
\hline & & \multirow[b]{2}{*}{$F$} & \multirow[b]{2}{*}{ Sig. } & \multirow[b]{2}{*}{$\mathrm{t}$} & \multirow[b]{2}{*}{ df } & \multirow[b]{2}{*}{$\begin{array}{l}\text { Sig. } \\
(2- \\
\text { tailed } \\
\quad) \\
\end{array}$} & \multirow[b]{2}{*}{$\begin{array}{c}\text { Mean } \\
\text { Differenc } \\
\text { e }\end{array}$} & \multirow[b]{2}{*}{$\begin{array}{c}\text { Std. } \\
\text { Error } \\
\text { Differenc } \\
\text { e }\end{array}$} & \multicolumn{2}{|c|}{$\begin{array}{c}95 \% \\
\text { Confidence } \\
\text { Interval of the } \\
\text { Difference }\end{array}$} \\
\hline & & & & & & & & & $\begin{array}{c}\text { Lowe } \\
r\end{array}$ & $\begin{array}{c}\text { Uppe } \\
\text { r }\end{array}$ \\
\hline \multirow{2}{*}{$\begin{array}{l}\text { GP } \\
A\end{array}$} & $\begin{array}{l}\text { Equal } \\
\text { varianc } \\
\text { es } \\
\text { assume } \\
\text { d }\end{array}$ & $\begin{array}{c}4.96 \\
6\end{array}$ & $\begin{array}{c}.02 \\
8\end{array}$ & $\begin{array}{c}1.62 \\
2\end{array}$ & 93 & .108 & .15731 & .09697 & $\begin{array}{c}- \\
.0352 \\
5\end{array}$ & $\begin{array}{c}.3498 \\
7\end{array}$ \\
\hline & $\begin{array}{l}\text { Equal } \\
\text { varianc } \\
\text { es not } \\
\text { assume } \\
\text { d }\end{array}$ & & & $\begin{array}{c}1.00 \\
4\end{array}$ & $\begin{array}{c}8.50 \\
5\end{array}$ & .343 & .15731 & .15662 & $\begin{array}{c}- \\
.2001 \\
5\end{array}$ & $\begin{array}{c}.5147 \\
7\end{array}$ \\
\hline
\end{tabular}

Table 5: GPAs Score and Gender

Further analysis has been carried out to find if there is a significant difference between GPA scores of female and male students as shown in Table 5. It is surprising when gender has no effect on academic performance in OER progressing implementation stage during ODL mode. This is contradicted with a previous study by Little and Jones (2020) who reported that male students outperform female students when they get better in the exam grades for online learning with OER than traditional classes. This contradiction could be due to the number of male students is scanty (14 students) compares to female students ( 94 students) to see a noteworthy impact on the analysis.

\section{Conclusion, Limitation \& Recommendation}

In conclusion, majority (more than half) of Accounting Undergraduates in UiTM Tapah have Agree-Strongly Agree to all the questions asked about their OER experiences during ODL. In this progressing implementation stage, the study found that the first year undergraduates believe that OER is a positive innovation that supports ODL sessions $(89.9 \%)$ though they have to change their study habit while using OER to support the ODL sessions $(83.3 \%)$. Nevertheless, students are confident with their ability to use OER during ODL (89.8\%) because of the observability they made, seen or heard about, from other university (80.6\%) and with the view of using OER during ODL is user friendly where students can save educational cost, apart from being IT savvy. Further analysis showed that GPA scores have significant differences in the early stage of OER implementation (traditional classroom mode) in comparing to progressing implementation stage during ODL session where students scored higher GPA during OER that has been implemented during ODL mode. Surprisingly, analysis on gender shows that, gender gave no effect on academic performance. Due to the findings, 
this study suggested that OER plays a strategic role in facilitating the wider collaboration of students and institutions across geographical boundaries in Malaysia, enhancing the quality of teaching and learning and reducing the educational costs for students especially during this pandemic crisis of COVID-19. At the bottom of all these potential advantages of OER during $\mathrm{ODL}$, is a robust technological infrastructure, high level of IT literacy, transparent legal framework, an abundance of tools and a positive attitude towards the benefits and value of OER. All the efforts and resources need to be syndicated for a better OER since it is a limelight of ODL. Apart from that, educators are also needed to be conversant with up-to-date IT skills and their applications to be able to benefit from using OER and thus giving the best experience for students in applying the OER in the future towards the stabilization stage of OER usage in this institution. Credits should be given to this institution in taking swift shifts in enhancing the implementation of OER during ODL sessions. This shift is another step forward towards globalising online learning, as documented in the Malaysian Education Blueprint. The main limitation of this study was a small sample size, which was the first-year undergraduate students. Thus generalisation of OER experiences amongst all first-year undergraduates of this institution is vague. A bigger sample may be collected from all the faculties in the future to provide a bigger picture of students' experience with OER, especially in this ODL session.

\section{References}

leh, M., Al-Twait, L., Al-Saht, G. (2020). The effect of online learning on communication between instructors and students during Covid-19 pandemic. Asian Education and Development Studies. https://doi.org/10.1108/AEDS-06-2020-0131

Alawamleh, M., Al-Twait, L., Al-Saht, G. (2020). The effect of online learning on communication between instructors and students during Covid-19 pandemic. Asian Education and Development Studies. https://doi.org/10.1108/AEDS-06-2020-0131

Alawamleh, M., Al-Twait, L., Al-Saht, G. (2020). The effect of online learning on communication between instructors and students during Covid-19 pandemic. Asian Education and Development Studies. https://doi.org/10.1108/AEDS-06-2020-0131

Abramovich, S., \& McBride, M. (2018). Open education resources and perceptions of financial value. The Internet and Higher Education, 39, 33-38. https://doi.org/10.1016/j.iheduc.2018.06.002

Afolabi, F. (2017). First Year Learning Experiences of University Undergraduates in the Use of Open Educational Resources in Online Learning. The International Review of Research in Open and Distributed Learning, 18(7). https://doi.org/10.19173/irrodl.v18i7.3167

Alawamleh, M., Al-Twait, L., Al-Saht, G. (2020). The effect of online learning on communication between instructors and students during Covid-19 pandemic. Asian Education and Development Studies. https://doi.org/10.1108/AEDS-06-2020-0131

Chang, I. (2020). Open versus Traditional Textbooks: A Comparison of Student Engagement and Performance. International Journal of Teaching and Learning in Higher Education, $32,3,488-498$.

Chaturvedi, K., Vishwakarma, D. K., \& Singh, N. (2021). COVID-19 and its impact on Education, Social Life and Mental Health of Student: A survey. Children and Youth Services Review, 121, 105866.

Debbarma, I., \& Durai, T. (2021). Educational Disruption: Impact of COVID-19 on Students from the Northeast State of India. Children and Youth Services Review, 120, 105769. 
Farrow, R., Pitt, R., de los Arcos, B., Perryman, L. A.,Weller, M., \& McAndrew, P. (2015). Impact of OER use on teaching and learning: Data from OER Research Hub (2013-2014). British Journal of Educational Technology, 46(5), 972-976.

http://dx.doi.org/doi:10.1111/bjet.12310

Feldstein, A., Martin, M., Hudson, A., Warren, K., Hilton III, J., \& Wiley, D. (2012). Open textbook and increased student access and outcomes. European Journal of Open, Distance, and E-Learning, 15(2), 1-9.

Fialkowski, M. K., Calabrese, A., Tilinghast, B., Titchenal, C. A., Meinke, W., Banna, J. C., \& Draper, J. (2020). Open educational resource textbook impact on students in an introductory nutrition course. Journal of Nutrition Education and Behavior, 52(4), 359368. https://doi.org/10.1016/j.jneb.2019.08.006

Fischer, L., Hilton III, J., Robinson, T. J., \& Wiley, D. A. (2015). A multi-institutional study of the impact of open textbook adoption on the learning outcomes of post-secondary students. Journal of Computing in Higher Education, 27(3), 159-172. https://doi.org/10.1007/s12528-015-9101-x

Hilton III, J. L. (2016). Open educational resources and college textbook choices: A review of research on efficacy and perceptions. Educational Technology Research and Development, 64(4), 573-590. https://doi.org/10.1007/s11423-016-9434-9

Howard, V. J. (2019). Open Educational Resources in Behavior Analysis. Behavior Analysis in Practise, 12, 839-853.

Kermanshachi, S., \& Nipa, T. J. (2018). Analysis and assessment of graduate students' perception and academic performance using open educational resource (OER) course materials. ASEE Annual Conference and Exposition.

Kurelovic, K. E. (2016). Advantages and limitations of usage of open educational resources in small countries. International Journal of Research in Education and Science (IJRES), 2(1), 136-142.

Little, P., \& Jones, B. (2020). A Comparison of student performance in face-to-face classes versus online classes versus hybrid classes using open educational resources. Journal of Instructional Pedagogies, 24, 1-10.

Mathew, S., \& Kashyap, U. (2019). Impact of OER Materials on Students' Academic Performance in Undergraduate Astronomy Course. Journal of STEM Education: Innovations and Research, 20(1), 46-49.

Ministry of Education Malaysia. (2015). Malaysian Education Blueprint 2015-2025 (Higher Education). Kementerian Pendidikan Malaysia. Retrieved from https://www.mohe.gov.my/en/download/publications-journals-and-reports/pppm2015-2025-pt/102-malaysia-education-blueprint-2015-2025-higher-education/file

Mishra, L., Gupta, T., \& Shree, A. (2020). Online Teaching-Learning in Higher Education during Lockdown Period of COVID-19 Pandemic. International Journal of Education Research Open 1, 100012.

Muthuprasad, T., Aiswayra, S., Adiyta, K. S., \& Jha, G. K. (2021). Students' Perception and Preference for Online Education in India During COVID-19 Pandemic. Social Sciences \& Humanities Open, 3, 100101.

Rahman, M. J. A., Daud, M. Y., \& Ensimau, N. K. (2019). Learning Management System (LMS) in Teaching and Learning. International Journal of Academic Research in Business and Social Sciences, 9(11), 1529-1535. 
Roeder, I., Severengiz, M., Stark, R., \& Seliger, G. (2017). Open Educational Resources as a Driver for Manufacturing-Related Education for Learning of Sustainable Development. Procedia Manufacturing, 8, 81-88.

Sultan, M., \& Rafiq, M. (2021). Open Access Information Resources and University Libraries: Analysis of Perceived Awareness, Challenges and Opportunities. The Journal of Academic Librarianship, 47, 102367.

Swigart, V., \& Liang, Z. (2016). Digital Resources for Nursing Education: Open Courseware and Massive Open Online Courses. International Journal of Nursing Sciences 3, 307-313.

Tang, H., Dhamija, A., Bodily, B., \& Learning, L. (2020). Understanding the impact of OER courses in relation to student socioeconomic status and employment. International Journal of Open Educational Resources ,3, 1, 47-72. https://doi.og/10.18278/ijoer.3.1.5

Muggli, V. J. I., \& Westermann, W. (2019). Effectiveness of OER use in first-year higher education students' mathematical course performance: A case study. International Review of Research in Open and Distributed Learning, 20(2), 205-222. https://doi.org/10.19173/irrodl.v20i2.3521

Ward, E. J., \& Lindshield, B. L. (2020). Performance, behaviour and perceptions of an open educational resource-derived interactive educational resource by online and campus university students. Research in Learning Technology, 28, 1-18. http://dx.doi.org/10.25304/rlt.v28.2386

Winitzky-Stephens, J. R., \& Pickavance, J. (2017). Open educational resources and student course outcomes: A multilevel analysis. International Review of Research in Open and Distributed Learning, 18(4), 35-49.

Zhao, Y., Satyanarayana, A., \& Cooney, C. (2020). Impact of Open Educational Resources (OER) on Student Academic Performance and Retention Rates in Undergraduate Engineering Departments. 